\title{
Pentraxin 3 Activates JNK Signaling and Regulates the Epithelial-To-Mesenchymal Transition in Renal Fibrosis
}

\author{
Tung-Wei Hung ${ }^{a, b}$ Jen-Pi Tsaic,d Shin-Huey Lin ${ }^{\mathrm{c}}$ Chien-Hsing Lee ${ }^{\mathrm{f}, \mathrm{g}} \quad$ Yi-Hsien Hsiehe,h \\ Horng-Rong Changa,b,i \\ Institute of Medicine, Chung Shan Medical University, Taichung, Taiwan, 'Division of Nephrology, \\ Department of Medicine, Chung Shan Medical University Hospital, Taichung, Taiwan, 'Division of \\ Nephrology, Dalin Tzu Chi Hospital, Buddhist Tzu Chi Medical Foundation, Chiayi, Taiwan. dSchool of \\ Medicine, Tzu Chi University, Hualien, Taiwan, eInstitute of Biochemistry, Microbiology and Immunology, \\ Chung Shan Medical University, Taichung, Taiwan, 'School of Chinese Medicine, College of Chinese \\ Medicine, China Medical University, Taichung, Taiwan, ${ }^{9}$ Division of Pediatric Surgery, Department of \\ Surgery, Children's Hospital of China Medical University, Taichung, hepartment of Biochemistry, School \\ of Medicine, Chung Shan Medical University, Taichung, Taiwan, 'School of Medicine, Chung Shan \\ Medical University, Taichung, Taiwan
}

\section{Key Words}

Pentraxin 3 • Epithelial-mesenchymal transition • Unilateral ureteral obstruction

\begin{abstract}
Background/Aims: Tubulointerstitial fibrosis can lead to end-stage renal disease. Pentraxin 3 (PTX3) is an acute phase protein produced by resident and innate immunity cells. We investigated the effect of PTX3 on cultured human proximal tubular epithelial (HK-2) cells and a rat unilateral ureteral obstruction (UUO) model of renal fibrosis. Methods: Gain-of-function experiments were used to examine the effect of recombinant human PTX3 (Rh-PTX3) on HK-2 cells. Cell proliferation (MTT assay) and in vitro cell migration were measured. The levels of PTX3, p-JNK, and EMT markers were measured using immunohistochemistry, RT-PCR, and western blotting in UUO rats and HK-2 cells. Results: HK-2 cells treated with Rh PTX3 did not affect cell viability, but significantly increased cell migration. Moreover, Rh-PTX3 increased the expression of snail, slug, $\mathrm{N}$-cadherin, and vimentin, decreased the expression of E-cadherin, and increased the phosphorylation of JNK. SP600126 (a specific JNK inhibitor) enhanced the effects of Rh-PTX3. Rats with UUO exhibited time-dependent increased levels of PTX3, p-JNK, and vimentin, and decreased expression of E-cadherin. Conclusions: Our results suggest that PTX3 induces cell migration via upregulation of EMT in a JNK-dependent mechanism, and highlight the role of PTX3 in the pathogenesis renal fibrosis.




\section{Introduction}

Chronic kidney disease (CKD) is a progressive condition characterized by scarring of renal tissue, more specifically glomerulosclerosis, interstitial fibrosis, and tubular atrophy, due to a variety of primary insults [1]. The pathogenesis of CKD includes deposition of interstitial matrix, loss of tubular cells, infiltration of inflammatory cells, fibroblast accumulation, and rarefaction of peritubular microvasculature. The onset and progression of CKD is greater in the presence of specific genetic polymorphisms, and tubulointerstitial fibrosis is the greatest morphologic predictor of clinical outcome and progression [1, 2]. The renal tubular epithelial cells of CKD patients undergo an epithelial-mesenchymal transition (EMT), and the increased expression of fibroblast-associated proteins and matrix deposition contribute to renal fibrosis $[3,4]$. During the EMT, there is increased expression of mesenchymal markers, such as $\alpha$-smooth muscle actin $(\alpha-S M A)$ and vimentin, and reduced expression of epithelial markers, such as E-cadherin, which is essential for the structural integrity of the renal epithelium [5]. Inflammation plays an important role in the initiation of renal fibrosis, and persistent inflammation after a chronic injury can promote fibrogenesis and further tissue damage [6].

Pentraxin 3 (PTX3), also called tumor necrosis factor (TNF) -inducible gene 14 protein (TSG-14), is a member of the superfamily of acute-phase proteins, including C-reactive protein (CRP) and serum amyloid P-component (SAP) [7]. Both resident and innate immune cells produce PTX3 in response to inflammatory signals, toll-like receptor (TLR) activation, microbial moieties, and intact microorganisms [8]. PTX3 levels are very low in the serum and tissues of normal subjects, but increase in response to inflammatory stimulation in many diseases, including infectious, autoimmune, and degenerative disorders $[9,10]$. Renal tubular epithelial cells produce PTX3 under inflammatory conditions [11]. Previous studies reported a negative correlation between plasma PTX3 concentration and kidney function [12].

The contribution of the EMT to renal fibrosis was debated until recent studies reported that mice with deletions of Twist and Snail, major transcriptional regulators of the EMT, had reduced renal fibrosis compared to wild-type mice [13]. Moreover, down-regulation of Snail in mice ameliorated inflammation and transforming growth factor (TGF)- $\beta$ expression, indicating a possible relationship of inflammation and fibrosis. In addition, recent studies demonstrated that the mitogen-activated kinase (MAPK) pathway regulates the EMT, and is related to the up-regulation of TGF- $\beta$ [14]. However, the intracellular signaling pathways underlying the PTX3-mediated EMT are not fully understood.

This study examined the intracellular signaling pathway in the PTX3-induced activation of JNK and the EMT in cultured human tubular epithelial cells and in rats subjected to unilateral ureteral obstruction (UUO), a model of renal fibrosis.

\section{Materials and Methods}

\section{Materials}

Anti-mouse and anti-rabbit IgG-conjugated horseradish peroxidase, and rabbit, mouse and goat polyclonal antibodies specific for $\beta$-actin (sc-47778), p-ERK1/2 (sc-16982), t-ERK (sc-292838), p-JNK1/2 (sc-6254), t-JNK1/2 (sc-571), p-p38 (sc-17852-R), and t-p38 (sc-7149) were purchased from Santa Cruz Biotechnology (Dallas, Texas). Epithelial-Mesenchymal Transition (EMT) Antibody Sampler (\#9782) was purchased from Cell Signaling Technology Inc. (Beverly, MA, USA). Anti-PTX3 antibodies (AF1826) and human recombinant-PTX3 (Rh-PTX3) protein were purchased from R\&D Technology (Minneapolis, MN). SP600125 was purchased from BioVision, Inc (Milpitas, California).

\section{Cell culture}

Human proximal tubular epithelial cells (HK-2; BCRC No. 60097) were obtained from the Bioresources Collection and Research Center, Food Industry Research and Development Institute (Hsinchu, Taiwan). These cells were cultured in keratinocyte serum-free medium (KSFM; Thermo Fisher Scientific, MA USA), 


\section{Cellular Physiology Cell Physiol Biochem 2016;40:1029-1038 and Biochemistry Published online: December 12, $2016 \quad \begin{aligned} & \text { DOI: } 2016 \text { The Author(s). Published by S. Karger AG, Basel } \\ & \text { www.karger.com/cpb }\end{aligned}$}

Hung et al.: Pentraxin 3 Regulates the EMT in Renal Fibrosis

supplemented with epidermal growth factor (EGF; $10 \mathrm{ng} / \mathrm{ml}$ ), bovine pituitary extract (BPE; $40 \mu \mathrm{g} / \mathrm{mL}$ ), and antibiotics (100 U/mL penicillin $\mathrm{G}, 100 \mathrm{mg} / \mathrm{mL}$ streptomycin) at $37^{\circ} \mathrm{C}$ in humidified air with $5 \% \mathrm{CO}_{2}$. The concentrations of Rh-PTX3 were the same as used previously $[15,16]$.

\section{Animal models}

All animal experiments were approved by the Institutional Animal Care and Use Committee of Chung Shan Medical University (IACUC: 1377). The UUO model was established in 7-week-old male Sprague-Dawley rats (weight: approximately 125 150 g) that were purchased from the National Laboratory Animal Center (Taipei, Taiwan). UUO was performed using an established protocol [17]. Briefly, rats were anaesthetized with sodium pentobarbital ( $50 \mathrm{mg} / \mathrm{kg}$ body weight), and the left ureter was double ligated. The right ureter was subjected to the same surgical procedures, but was not ligated. Rats were killed after 7 or 14 days, and kidney tissues were removed for analysis by western blotting and immunohistochemical assays.

MTT assay

The effect of Rh-PTX3 on the viability of HK-2 cells was determined using the MTT assay [18]. Briefly, 24-well plates were plated in triplicate, with $2 \times 10^{4}$ cells per well. After $24 \mathrm{~h}$ of incubation, cells were treated with various concentrations of the Rh-PTX3 (0, 100 and $200 \mathrm{ng} / \mathrm{ml}$ ) for 24 or $48 \mathrm{~h}$. Then $100 \mu \mathrm{L}$ of MTT solution $(5 \mathrm{mg} / \mathrm{mL})$ was added to each well, and the cells were incubated for $2 \mathrm{~h}$ at $37^{\circ} \mathrm{C}$. The medium was removed, $100 \mu \mathrm{L}$ of isopropanol was added to each well, and the absorbance at $570 \mathrm{~nm}$ was measured.

\section{Migration assays}

For the migration assay, HK- 2 cells $\left(2 \times 10^{5}\right.$ cells/well $)$ were treated with Rh-PTX3, and then trypsinized and resuspended in KSFM. Then $5 \times 10^{5}$ cells were placed in the upper chamber of the well insert with polyvinylpyrrolidone-free polycarbonate filters (Millipore; 8-mm pore size). KSFM with 10\% FBS was placed in the lower chamber, and HK-2 cells were then incubated for $36 \mathrm{~h}$ at $37^{\circ} \mathrm{C}$, stained with $0.05 \%$ Giemsa, and then counted under a light microscope $(\times 200)$. This experiment was performed three times independently and the data are presented as means \pm standard deviations of triplicate samples of 5 fields.

\section{RT-PCR}

Total RNA was extracted from synovial fibroblasts using a TRIzol kit (Thermo Fisher Scientific). RTPCR was performed in triplicate. Each $25 \mu \mathrm{L}$ reaction contained $2 \mu \mathrm{L}$ of cDNA, $1 \mu \mathrm{L}$ of each primer $(10$ $\mu \mathrm{M}$ each), and $12.5 \mu \mathrm{L}$ of GoTaq® Green Master Mix (Promega). Primers used were: For PTX3 (322 bp): forward 5'-CTGTATCTCAGCTACCAATCCA-3' and reverse 5'-TTGCTAAGAACACTATCCCAGA-3'. E-cadherin (362 bp): forward 5'-TCCATTTCTTGGTCTACGCCT-3' and reverse 5'- TCACCTTCAGCCATCCTGTTT-3'. For Snail (300 bp): forward 5'-CTGCAGGACTCTAATCCAG-3' and reverse 5'-CAAGGAAGAGGCTGAAGTAG-3'. For Slug (174 bp): forward 5'-GCCTCCAAAAAGCCAAACTACAG-3' and reverse 5'-ACAGTGATGGGGCTGTATGC-3'. For Vimentin (440 bp): forward 5'- AGGAAATGGCTCGTCACCTTCGTGAATA-3' and reverse 5'AGGAGTTCGGTTGTTAAGAACTAGAGC-3'. For N-cadherin (191 bp): forward 5'-CGAGCCGCCTGCGCTGCCAC-3 andreverse 5'-CGCTGCTCTCCGCTCCCCGC-3'.For $\beta$-actin (502 bp): forward 5'-GCACTCTTCCAGCCTTCCTTCC-3' and reverse 5'- TCACCTTCACCGTTCCAGTTTTT-3'. Expression of all target genes was normalized to that of $\beta$-actin.

\section{Western blot analysis.}

Cellular lysates were prepared and resolved on SDS-PAGE and transferred to Immobilon polyvinyl difluoride (PVDF) membranes. The blots were blocked with 4\% BSA for $1 \mathrm{~h}$ at room temperature, and then probed overnight at $4^{\circ} \mathrm{C}$ with rabbit anti-human antibodies against $\beta$-actin $(200 \mu \mathrm{g} / \mathrm{ml}), \mathrm{p}$-ERK1/2 (200 $\mu \mathrm{g} / \mathrm{ml}), \mathrm{t}-\mathrm{ERK} 1 / 2(200 \mu \mathrm{g} / \mathrm{ml}), \mathrm{p}-J \mathrm{NK} 1 / 2(200 \mu \mathrm{g} / \mathrm{ml}), \mathrm{t}-J \mathrm{NK} 1 / 2(200 \mu \mathrm{g} / \mathrm{ml}), \mathrm{p}-\mathrm{p} 38(100 \mu \mathrm{g} / \mathrm{ml})$, and t-p38 $(200 \mu \mathrm{g} / \mathrm{ml})$ or PTX3 $(100 \mu \mathrm{g} / \mathrm{ml})$. After 3 washes, the blots were incubated with donkey antirabbit peroxidase-conjugated secondary antibody for $1 \mathrm{~h}$ at room temperature. All blots were visualized by enhanced chemiluminescence using a Luminescent Image Analyzer LAS-4000 mini.

Cytokine detection

PTX3 was measured in the supernatant using ELISA kits (R\&D systems, Minneapolis, MN, USA) according to the manufacturer's instructions. 


\section{Immunohistochemical assay}

PTX3,_E-cadherin, p-JNK1/2, and vimentin protein products from the control and UUO rats of each group were measured by immunohistochemical analysis, as previously described [19]. This analysis employed anti-PTX3 $(100 \mu \mathrm{g} / \mathrm{ml})$, anti-E-cadherin $(0.91 \mathrm{mg} / \mathrm{ml})$, anti-vimentin $(9 \mu \mathrm{g} / \mathrm{ml})$, or anti-p-JNK $(200$ $\mu \mathrm{g} / \mathrm{ml}$ ). Two independent pathologists, who were blinded to the treatment groups, reviewed the sections by light microscopy $(\times 40)$. Ten fields of interest were selected, and the percentage of immunohistochemically positive cells was determined for each selected field. Quantification of staining was performed automatically by the software. Images were captured using a Nikon inverted microscope (Eclipse, Tokyo, Japan).

\section{Statistical analysis}

All data are expressed as means \pm standard errors. Statistical analysis was performed with GraphPad Prism 5. Analysis of variance (ANOVA) and the unpaired 2-tailed Student's t-test were used to determine the significance of differences.

\section{Results}

Effect of PTX3 on viability and migration of human proximal tubular epithelial cell line HK-2 cells

Previous research demonstrated that PTX3 is an important mediator of tissue fibrosis $[20,21]$. Thus, we treated HK-2 cells with different concentrations of Rh-PTX3 $(0,50,100$, and $200 \mathrm{ng} / \mathrm{ml}$ ) for $24 \mathrm{~h}$, and measured PTX3 by western blotting. As expected, the results show that Rh-PTX3 significantly increased PTX3 expression in a concentration-dependent manner (Fig. 1A). Using the anti-His antibody detected the exogenous Rh-PTX3 by western blots to suggest the low level of exogenous Rh-PTX3 in $100 \mathrm{ng} / \mathrm{ml}$ Rh-PTX3 treated cells (Fig. 1B). However, treatment of cells with 100 or $200 \mathrm{ng} / \mathrm{ml} \mathrm{Rh-PTX3} \mathrm{for} 24$ and $48 \mathrm{~h}$ had no effect on cell viability (Fig. 1C). We also assessed the effects of PTX3 on the cell migration. The results show that Rh-PTX3 increased cell migration in a dose-dependent manner (Fig. 1D). Thus, Rh-PTX3 significantly increased the migration of HK-2 cells but had no toxic effects at the tested concentrations.

Fig. 1. PTX3 induces migration of human proximal tubular epithelial (HK-2) cells. (A) Western blotting of PTX3 in HK-2 cells treated with Rh-PTX3 $(0,50,100$, and 200 $\mathrm{ng} / \mathrm{ml}$ ) at $24 \mathrm{~h}$. (B) Cell viability was detected by MTT assay. (C) Exogenous Rh-PTX3 was detected by western blotting. (D) Cell migration assay with representative images (upper panel) and the quantification (lower panel). Scale bars: $100 \mu \mathrm{m}$. The histogram represents the densitometric analysis of relative protein expression. $\beta$-actin was used as internal loading control. Data are from at three independent experiments, and the means \pm SDs are indicated. ${ }^{* *} P<0.01$ compared with control (0 ng/ml).

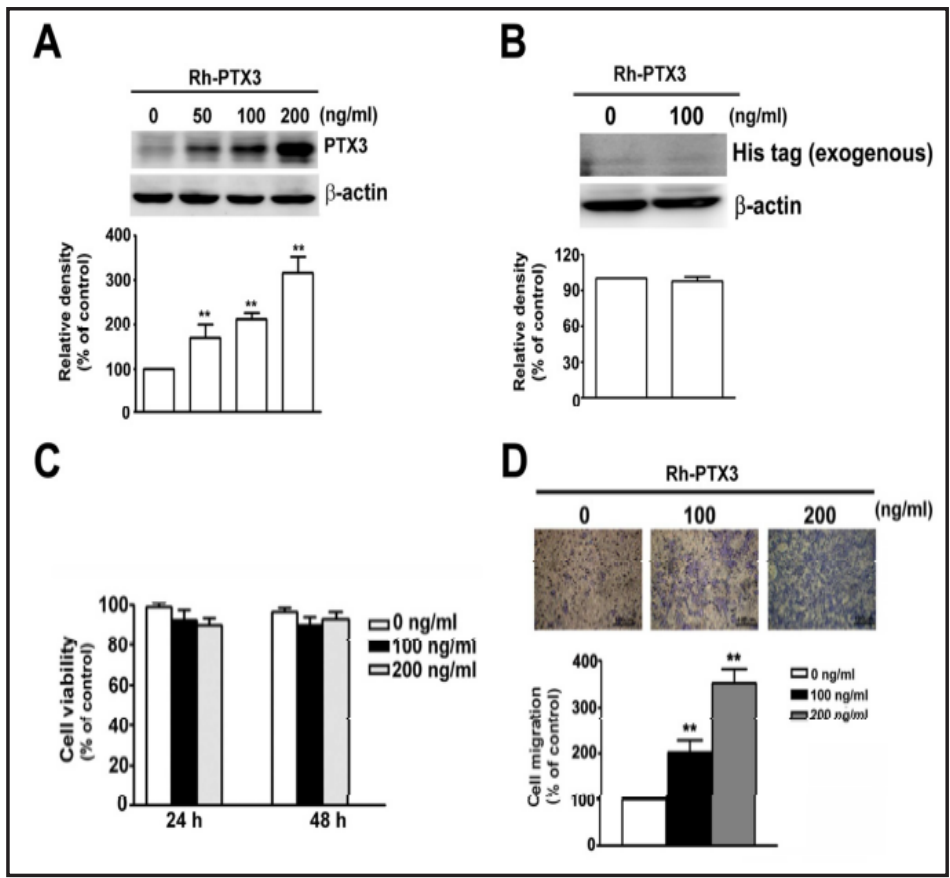



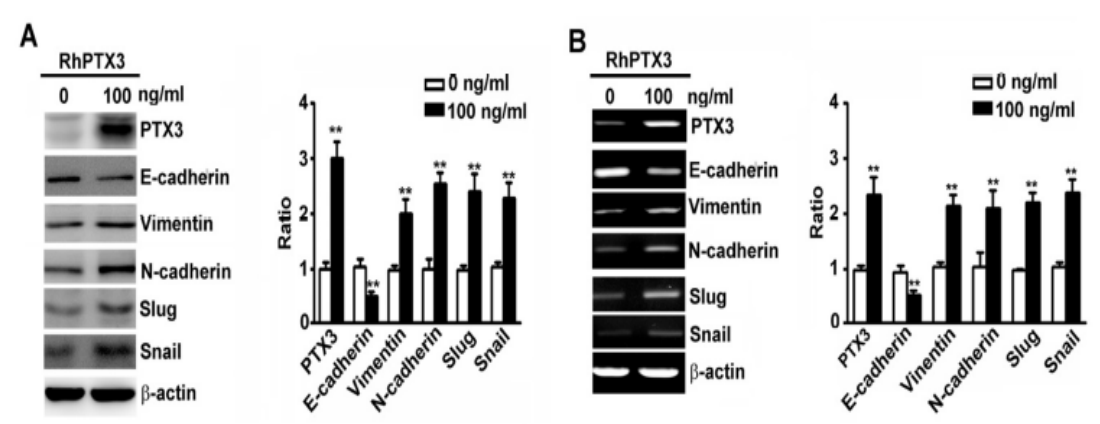

Fig. 2. PTX3 induces the EMT in HK-2 cells. (A) Western blotting analysis of PTX3, mesenchymal markers (vimentin, N-cadherin, Snail, and Slug), and an epithelial marker (E-cadherin) in HK-2 cells treated for 24 $\mathrm{h}$ in the absence or present of Rh-PTX3 (100 ng/ml). The histogram represents the densitometric analysis of relative protein expression. (B) RT-PCR analysis of the PTX3 and same markers following the same treatment. Gene expression is expressed as relative mRNA levels. Data are from at three independent experiments, and the means \pm SDs are indicated. ${ }^{* *} P<0.01$ compared with control $(0 \mathrm{ng} / \mathrm{ml})$.

Fig. 3. PTX3 induces JNK1/2 activation in HK-2 cells. Western blotting of $\mathrm{p}$-ERK1/2, p-p38, and p-JNK1/2 in HK-2 cells treated with Rh-PTX3 (100 $\mathrm{ng} / \mathrm{ml}$ ) for the indicated times. The histogram represents the densitometric analysis of relative protein expression. $\beta$-actin was used as internal loading control. Data are from at three independent experiments, and the means \pm SDs are indicated. ${ }^{* *} P<0.01$ compared with control $(0 \mathrm{ng} / \mathrm{ml})$.

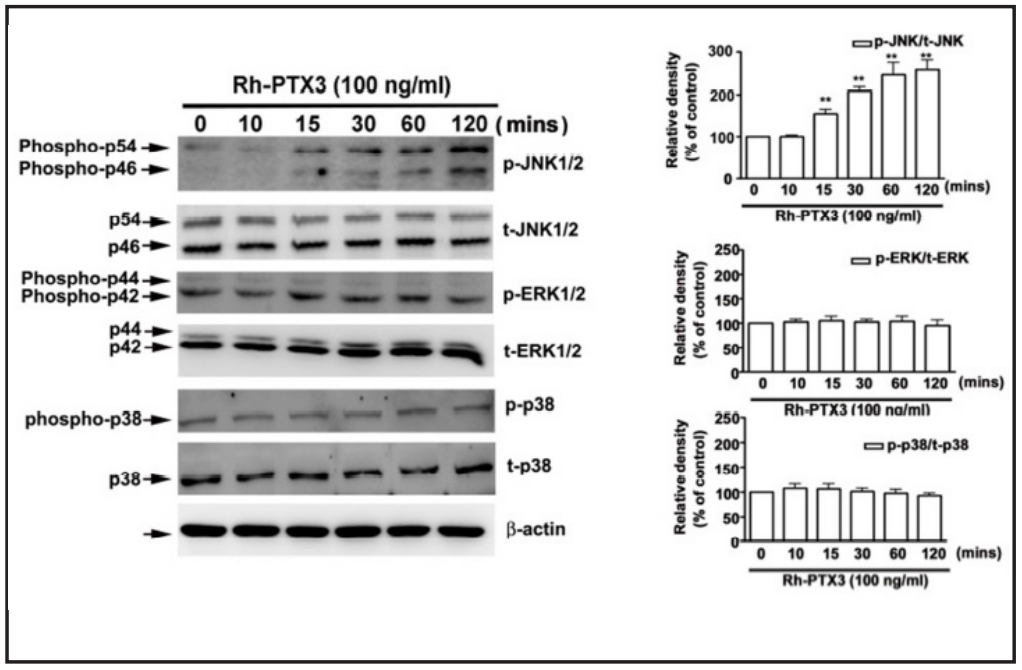

\section{PTX3 induced epithelial mesenchymal transition in $\mathrm{HK}-2$ cells}

Renal fibrosis is a multifactorial and multifaceted disease, and there is evidence that cells undergo an EMT, with increased migratory potential and significant changes in gene expression [22]. Thus, we measured the expression of EMT marker genes by western blotting in Rh-PTX3-treated HK-2 cells. The results show that Rh-PTX3 decreased the expression of the epithelial marker E-cadherin, but increased the expression of the mesenchymal markers Snail and Slug, the mesenchymal intermediate filament vimentin, and the cell adhesion molecule N-cadherin (Fig. 2A). The RT-PCR results were similar (Fig. 2B). These results indicate that PTX3 promotes the trans-differentiation of epithelial cells to mesenchymal cells in renal fibrosis.

\section{PTX3 induces EMT progression through the JNK pathway}

Previous research demonstrated that MAPKs have a role in the EMT progression [23]. Thus, we examined the role of the MAPK pathway in PTX3-mediated EMT progression. The results show that PTX3 induced a significant increase in the phosphorylation of JNK1/2 in a time-dependent manner, but had no effect on the phosphorylation of ERK1/2 or p-38 (Fig. 3).

\section{KARGER}




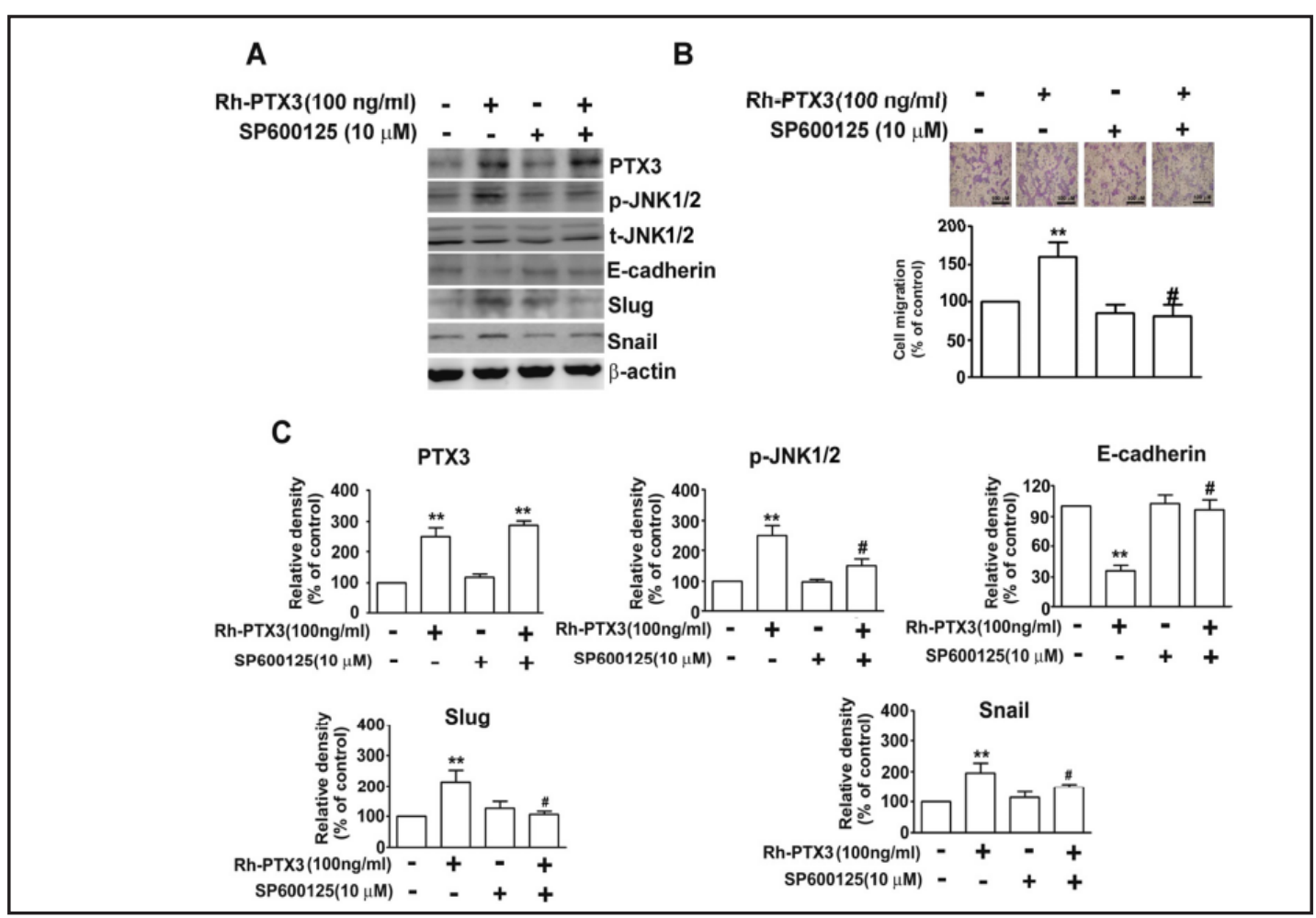

Fig. 4. Inhibition of JNK1/2 phosphorylation blocks cell migration and the EMT of HK-2 cells. (A and C) Western blotting of HK-2 cells pretreated for $2 \mathrm{~h}$ in the absence or presence of SP600125 $(10 \mu \mathrm{M})$, with addition of Rh-PTX3 (100 ng/ml) for $24 \mathrm{~h}$. Total cell lysates were used to examine the phosphorylation of JNK1/2, total-JNK1/2, E-cadherin, slug, and snail. (B) Cell migration assay of HK-2 cells. Scale bars: $100 \mu \mathrm{m}$. The histogram represents the densitometric analysis of relative protein expression. $\beta$-actin was used as internal loading control. ${ }^{* *} P<0.01$ compared with control $(0 \mathrm{ng} / \mathrm{ml})$. \# $P<0.01$ compared with Rh-PTX3.

Effect of JNK activity on PTX3-induced EMT expression and cell migration

Next, we examined the role of the JNK pathway in the PTX3-mediated enhancement of the EMT. Thus, we pretreated HK-2 cells with SP600125 $(10 \mu \mathrm{M})$, a specific inhibitor of JNK kinase [24] before treatment with PTX3 (100 ng/ml). The results show that Rh-PTX3 alone increased the phosphorylation of JNK, increased the expression of slug and snail, and decreased the expression of E-cadherin (Fig. 4A). However, pre-treatment with SP600125 for $2 \mathrm{~h}$ before the addition of Rh-PTX3 significantly inhibited this response. Moreover, treatment with Rh-PTX3 increased the migration of HK-2 cells, but pre-treatment with SP600125 also inhibited this response (Fig. 4B). These results indicate that the PTX3-induced EMT is mediated via the JNK signaling pathway.

PTX3 expression is altered in kidneys with UUO-induced kidney fibrosis

Finally, we investigated the role of PTX3 in the progression of kidney fibrosis in the rat UUO model. Thus, we performed an immunohistochemistry analysis of the kidneys of rats subjected to UUO at 0,7 , and 14 days. The results show that the obstructed kidney had increased levels of PTX3, p-JNK1/2, and vimentin and low expression of E-cadherin on days 7 and 14 relative to day 0 (Fig. 5B, right). However, the unobstructed kidney had no such changes (Fig. 5A, left). The western blotting results were similar (Figs. 5C and 5D). In addition, we showed that the increased levels of serum PTX3 on days 7 and 14 relative to day 0 (Figs. 5E). The results of this rat UUO model agree with those of the HK-2 experiments, and indicate that PTX3 has a role in the pathogenesis of renal fibrosis. 

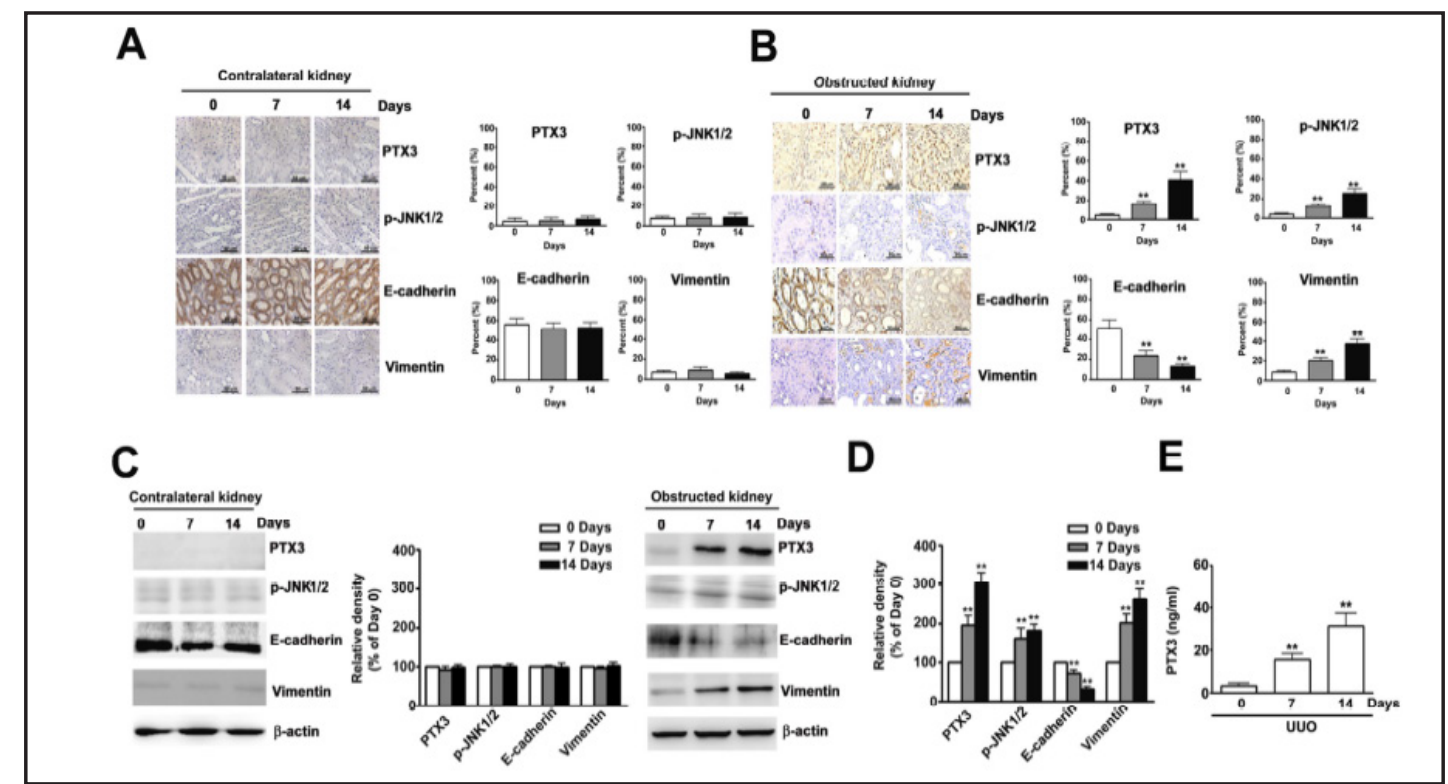

B

Fig. 5. JNK activation has a role in EMT signaling in the rat model of renal fibrosis. Immunohistochemical staining of PTX3, p-JNK1/2, E-cadherin and vimentin in the (A) contralateral kidney and (B) obstructed kidney rat after surgery for 0,7 and 14 days. Magnification: $\times 400$. Scale bars: $50 \mu \mathrm{m}$. (C.D) The effects of the contralateral kidney and obstructed kidney on expression of PTX3, p-JNK1/2, E-cadherin and vimentin, respectively by western blot analysis. (E) The serum of PTX3 expression was determined by ELISA assay analysis. The histogram represents the densitometric analysis of relative protein expression. $\beta$-actin was used as internal loading control. Data are from at three independent experiments, and the means \pm SDs are indicated. ${ }^{* *} P<0.01$ compared with control (Day 0 ).

\section{Discussion}

The EMT is believed to underlie the development of fibrosis in chronic renal failure. Accordingly, the progression of renal fibrosis parallels the upregulation of EMT-driving transcription factors, including Snail, Slug, vimentin, and N-cadherin, and the downregulation of E-cadherin [25]. In this study, we found that exogenous PTX3 induced cell migration through phosphorylation of JNK1/2 and promotion of the EMT in HK-2 cells. Furthermore, we found increased levels of PTX3, p-JNK1/2, and vimentin and a decreased level of E-cadherin in a rat UUO model of renal fibrosis. These results indicate that PTX3 and phosphorylation of JNK1/2 appear to be involved in the development of renal fibrosis.

Resident and innate immunity cells produce PTX3, a member of the super-family of acute-phase proteins, in response to inflammatory signals or infection [7, 8]. Moreover, macrophages and a variety of tissue cells produce PTX3 upon exposure to primary inflammation signals, such as TNF- $\alpha$, interleukin (IL) $-1 \beta$, and lipopolysacharide (LPS) [26]. PTX3 also has a role in the pathogenesis of acute and chronic kidney diseases [27]. Multiple studies have reported negative correlations between plasma PTX3 concentration and kidney function [12]. These results suggest that renal interstitial fibroblasts may synthesize PTX3 in the injured interstitium. Studies from our laboratory demonstrated that PTX3 induces the EMT in tubular epithelial cells. In particular, a previous study reported that increased expression of PTX3 in the proximal renal tubular epithelial cells occurred in proinflammatory conditions, and PTX3 appeared to play a role in the innate immune response and inflammatory reactions in the kidney [28]. In agreement, the present study shows that PTX3 expression in tubular epithelial cells increased over time in the rat UUO model of renal fibrosis. 
Numerous factors regulate the EMT, including growth factors, cytokines, hormones, and extracellular cues of different pathways $[29,30]$. During the EMT, epithelial cells acquire mesenchymal-like properties through disruption of intercellular adhesion and enhancement of cell motility. The present study confirmed the PTX3-mediated induction of the EMT in HK-2 cells based on morphological changes, reduced expression of E-cadherin, increased expression of vimentin and N-cadherin, and increased migration. The UUO rat model, also had higher levels of PTX3, p-JNK1/2, and vimentin and a lower level of E-cadherin at day 7 and 14 relative to day 0 . Thus, PTX3 appears to have an important role in the pathogenesis of renal fibroblasts in the obstructed kidney.

The MAPKs are a family of serine/threonine kinases activated by growth and stress factors that play a key role in intracellular signal transduction. In response to stimuli, 3 MAPK protein subfamilies can be activated: ERK, SAPK/JNK, and p38. Previous research indicates that MAPKs have major roles in many pathophysiological processes associated with kidney disease [31, 32]. Rui et al. reported that aristolochic acid (AA) induced TGF- $\beta 1$ in human renal proximal tubule epithelial cells, and that this is mediated via JNK-dependent AP-1 activation [33]. TNF- $\alpha$-induced PTX3 expression is also mediated through the JNK pathway in human lung epithelial cells [26]. In addition, Zhang et al. reported that a JNK inhibitor (SP600125) and an ERK inhibitor (U0126) significantly inhibited the TNF-induced PTX3 expression in human airway smooth muscle cells [34]. In the present study, we found that PTX3 activated the JNK1/2 pathway in HK-2 cells and that pretreatment with a specific inhibitor demonstrated that this effect was mediated via JNK1/2, not ERK1/2 or p38. Our experiments demonstrated that SP600125, which specifically blocks JNK1/2 activation, significantly decreased PTX3-induced slug and snail expression and increased E-cadherin expression. Thus, PTX3 is an important upstream activator of JNK signaling in the obstructed kidney in vivo and in HK2 cells.

In conclusion, our results suggest that PTX3 has an important role and may be a key factor in the promotion of renal fibrosis. PTX3 induces slug and snail expression and decreases E-cadherin expression in HK-2 cells via phosphorylation of JNK1/2. This study provides important information about the role of PTX3 and the JNK 1/2 signaling pathway in the development of the renal tubule EMT and renal fibrosis, and suggests that PTX3 should be considered a candidate target for treatment of renal fibrosis.

\section{Acknowledgements}

This work was supported by grants from Chung Shan Medical University Hospital, Taiwan (CSH-2013-C-009 and CSH-2013-C-028) and China Medical University Hospital, Taiwan (DMR-105-035).

\section{Disclosure Statement}

The authors declare that they have no competing interests.

\section{References}

1 Liu Y: Cellular and molecular mechanisms of renal fibrosis. Nat Rev Nephrol 2011;7:684-696.

2 Strutz F, Okada H, Lo CW, Danoff T, Carone RL, Tomaszewski JE, Neilson EG: Identification and characterization of a fibroblast marker: FSP1. J Cell Biol 1995;130:393-405.

3 Yang J, Liu Y: Dissection of key events in tubular epithelial to myofibroblast transition and its implications in renal interstitial fibrosis. Am J Pathol 2001;159:1465-1475.

4 Pan B, Liu G, Jiang Z, Zheng D: Regulation of renal fibrosis by macrophage polarization. Cell Physiol Biochem 2015;35:1062-1069. 


\section{Cellular Physiology Cell Physiol Biochem 2016;40:1029-1038

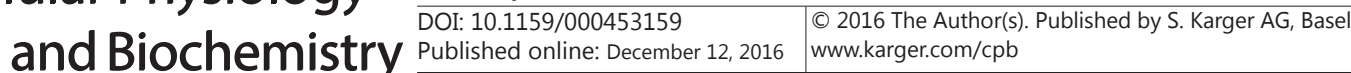

Hung et al.: Pentraxin 3 Regulates the EMT in Renal Fibrosis

5 Liu Y: New insights into epithelial-mesenchymal transition in kidney fibrosis. J Am Soc Nephrol 2010;21:212-222.

6 Jinde K, Nikolic-Paterson DJ, Huang XR, Sakai H, Kurokawa K, Atkins RC, Lan HY: Tubular phenotypic change in progressive tubulointerstitial fibrosis in human glomerulonephritis. Am J Kidney Dis 2001;38:761-769.

7 Imai N, Nishi S, Yoshita K, Ito Y, Osawa Y, Takahashi K, Nakagawa Y, Saito K, Narita I: Pentraxin-3 expression in acute renal allograft rejection. Clin Transplant 2012;24:S25-31.

8 Bottazzi B, Doni A, Garlanda C, Mantovani A: An integrated view of humoral innate immunity: pentraxins as a paradigm. Annu Rev Immunol 2010;28:157-183.

9 Luchetti MM, Piccinini G, Mantovani A, Peri G, Matteucci C, Pomponio G, Fratini M, Fraticelli P, Sambo P, Di Loreto C, Doni A, Introna M, Gabrielli A: Expression and production of the long pentraxin PTX3 in rheumatoid arthritis (RA). Clin Exp Immunol 2000;119:196-202.

10 Bussolati B, Peri G, Salvidio G, Verzola D, Mantovani A, Camussi G: The long pentraxin PTX3 is synthesized in IgA glomerulonephritis and activates mesangial cells. J Immunol 2003;170:1466-1472.

11 Nauta AJ, de Haij S, Bottazzi B, Mantovani A, Borrias MC, Aten J, Rastaldi MP, Daha MR, van Kooten C, Roos A: Human renal epithelial cells produce the long pentraxin PTX3. Kidney Int 2005;67:543-553.

12 Tong M, Carrero JJ, Qureshi AR, Anderstam B, Heimburger O, Barany P, Axelsson J, Alvestrand A, Stenvinkel P, Lindholm B, Suliman ME: Plasma pentraxin 3 in patients with chronic kidney disease: associations with renal function, protein-energy wasting, cardiovascular disease, and mortality. Clin J Am Soc Nephrol 2007;2:889-897.

13 Lovisa S, LeBleu VS, Tampe B, Sugimoto H, Vadnagara K, Carstens JL, Wu CC, Hagos Y, Burckhardt BC, Pentcheva-Hoang T, Nischal H, Allison JP, Zeisberg M, Kalluri R: Epithelial-to-mesenchymal transition induces cell cycle arrest and parenchymal damage in renal fibrosis. Nat Med 2015;21:998-1009.

14 Ellenrieder V, Hendler SF, Boeck W, Seufferlein T, Menke A, Ruhland C, Adler G, Gress TM: Transforming growth factor beta1 treatment leads to an epithelial-mesenchymal transdifferentiation of pancreatic cancer cells requiring extracellular signal-regulated kinase 2 activation. Cancer Res 2001;61:4222-4228.

15 Choi B, Lee EJ, Song DH, Yoon SC, Chung YH, Jang Y, Kim SM, Song Y, Kang S. W, Yoon SY, Chang EJ: Elevated Pentraxin 3 in bone metastatic breast cancer is correlated with osteolytic function. Oncotarget 2014;5:481-492.

16 Ying TH, Lee CH, Chiou HL, Yang SF, Lin CL, Hung CH, Tsai JP, Hsieh YH: Knockdown of Pentraxin 3 suppresses tumorigenicity and metastasis of human cervical cancer cells. Sci Rep 2016;6:29385.

17 Jones LK, O'Sullivan KM, Semple T, Kuligowski MP, Fukami K, Ma FY, Nikolic-Paterson DJ, Holdsworth SR, Kitching AR: IL-1RI deficiency ameliorates early experimental renal interstitial fibrosis. Nephrol Dial Transplant 2009;24:3024-3032.

18 Tsai JP, Lee CH, Ying TH, Lin CL, Hsueh JT, Hsieh YH: Licochalcone A induces autophagy through PI3K/Akt/ mTOR inactivation and autophagy suppression enhances Licochalcone A-induced apoptosis of human cervical cancer cells. Oncotarget 2015;6:28851-28866.

19 Wang B, Ding W, Zhang M, Li H, Gu Y: Rapamycin attenuates aldosterone-induced tubulointerstitial inflammation and fibrosis. Cell Physiol Biochem 2015;35:116-125.

20 Pilling D, Cox N, Vakil V, Verbeek JS, Gomer RH: The long pentraxin PTX3 promotes fibrocyte differentiation. PLoS One 2015;10:e0119709.

21 Iwano M, Plieth D, Danoff TM, Xue C, Okada H, Neilson EG: Evidence that fibroblasts derive from epithelium during tissue fibrosis. J Clin Invest 2002;110:341-350.

$22 \mathrm{He}$ J, Xu Y, Koya D, Kanasaki K: Role of the endothelial-to-mesenchymal transition in renal fibrosis of chronic kidney disease. Clin Exp Nephrol 2013;17:488-497.

23 Stambe C, Atkins RC, Tesch GH, Masaki T, Schreiner GF, Nikolic-Paterson, DJ: The role of p38alpha mitogenactivated protein kinase activation in renal fibrosis. J Am Soc Nephrol 2004;15:370-379.

24 Liu QR, Liu JM, Chen Y, Xie XQ, Xiong XX, Qiu XY, Pan F, Liu D, Yu SB, Chen XQ: Piperlongumine inhibits migration of glioblastoma cells via activation of ROS-dependent $\mathrm{p} 38$ and JNK signaling pathways. Oxid Med Cell Longev 2014;2014:653732.

25 Liu Y: Epithelial to mesenchymal transition in renal fibrogenesis: pathologic significance, molecular mechanism, and therapeutic intervention. J Am Soc Nephrol 2004;15:1-12. 


\section{Cellular Physiology Cell Physiol Biochem 2016;40:1029-1038 \begin{tabular}{ll|l} 
DOI: 10.1159/000453159 & $\begin{array}{l}\text { O 2016 The Author(s). Published by S. Karger AG, Basel } \\
\text { www.karger.com/cpb }\end{array}$
\end{tabular} \\ Hung et al.: Pentraxin 3 Regulates the EMT in Renal Fibrosis}

26 Han B, Mura M, Andrade CF, Okutani D, Lodyga M, dos Santos CC, Keshavjee S, Matthay M, Liu M: TNFalphainduced long pentraxin PTX3 expression in human lung epithelial cells via JNK. J Immunol 2005;175:83038311.

27 Lech M, Römmele C, Gröbmayr R, Eka Susanti H, Kulkarni OP, Wang S, Gröne HJ, Uhl B, Reichel C, Krombach F, Garlanda C, Mantovani A, Anders HJ: Endogenous and exogenous pentraxin-3 limits postischemic acute and chronic kidney injury. Kidney Int 2013;83:647-661.

28 Yilmaz MI, Siriopol D, Saglam M, Kurt YG, Unal HU, Eyileten T, Gok M, Cetinkaya H, Oguz Y, Sari S, Vural A, Mititiuc I, Covic A, Kanbay M: Plasma endocan levels associate with inflammation, vascular abnormalities, cardiovascular events, and survival in chronic kidney disease. Kidney Int 2014;86:1213-1220.

29 Rastaldi MP, Ferrario F, Giardino L, Dell'Antonio G, Grillo C, Grillo P, Strutz F, Müller GA, Colasanti G, D'Amico G: Epithelial-mesenchymal transition of tubular epithelial cells in human renal biopsies. Kidney Int 2002;62:137-146.

$30 \mathrm{Hu}$ J, Zhu Q Li PL, Wang W, Yi F, Li N: Stem cell conditioned culture mediaattenuated albumin-induced epithelial-mesenchymal transition in renal tubular cells. Cell Physiol Biochem 2015;35:1719-1728.

31 Chin BY, Mohsenin A, Li SX, Choi AM, Choi ME: Stimulation of pro-alpha(1)(I) collagen by TGF-beta(1) in mesangial cells: role of the p38 MAPK pathway. Am J Physiol Renal Physiol 2001;280:F495-504.

32 Watanabe H, de Caestecker MP, Yamada Y: Transcriptional cross-talk between Smad, ERK1/2, and p38 mitogen-activated protein kinase pathways regulates transforming growth factor-beta-induced aggrecan gene expression in chondrogenic ATDC5 cells. J Biol Chem 2001;276:14466-14473.

33 Rui HL, Wang YY, Cheng H, Chen YP: JNK-dependent AP-1 activation is required for aristolochic acidinduced TGF-beta1 synthesis in human renal proximal epithelial cells. Am J Physiol Renal Physiol 2012;302:F1569-1575.

34 Zhang J, Koussih L, Shan L, Halayko AJ, Chen BK, Gounni AS: TNF up-regulates Pentraxin3 expression in human airway smooth muscle cells via JNK and ERK1/2 MAPK pathways. Allergy Asthma Clin Immunol 2015;11:37. 